\title{
The (un)desirability of immortality
}

\section{Felipe Pereira | Travis Timmerman $₫$}

\author{
Department of Philosophy, Seton Hall \\ University, South Orange, New Jersey

\section{Correspondence} \\ Travis Timmerman, Department of \\ Philosophy, Seton Hall University, South \\ Orange, NJ. \\ Email: travis.timmerman@shu.edu
}

\begin{abstract}
While most people believe the best possible life they could lead would be an immortal one, so-called "immortality curmudgeons" disagree. Following Bernard Williams, they argue that, at best, we have no prudential reason to live an immortal life, and at worst, an immortal life would necessarily be bad for creatures like us. In this article, we examine Bernard Williams' seminal argument against the desirability of immortality and the subsequent literature it spawned. We first reconstruct and motivate Williams' somewhat cryptic argument in three parts. After that, we elucidate and motivate the three best (and most influential) counterarguments to Williams' seminal argument. Finally, we review, and critically examine, two further distinct arguments in favor of the anti-immortality position.

\section{KEYWORDS}

death, desirability, immortality, Makropulos, rational preference, Williams
\end{abstract}

\section{1 | INTRODUCTION}

The majority of people believe in an afterlife where they will (in some sense) live forever. ${ }^{1}$ Likely an even greater percentage of people believe that this would be the best outcome, even if they do not think it is a realistic possibility. Some philosophers, however, disagree. So-called "immortality curmudgeons" believe that any immortal life would not be good for creatures like us or, at least, not be a life that we currently have any reason to want to live. In this article, we examine Bernard Williams' seminal argument against the desirability of immortality and the subsequent literature it spawned. In Section 2, we reconstruct Williams' argument in three parts and, in doing so, motivate the contentious premises. In Section 3, we elucidate the best and most influential counterarguments to Williams' seminal argument. Finally, in Sections 4 and 5, we review, and critically examine, two further distinct arguments in favor of the anti-immortality position. 


\section{2 | WILLIAMS' ARGUMENT AGAINST THE DESIRABILITY OF IMMORTALITY}

"The Makropulos Case" is the title of a play written by Karel Čapek, which tells the story of Elina Makropulos, a woman who acquires the elixir of life at the "biological" age of 37. The elixir extends her "chronological" life 300 years, while keeping her stuck at the "biological" age of $37 .^{2}$ However, after 300 years, she finds her unending life deeply dull and empty. So she resolves not to drink from the elixir again and dies soon after.

In a chapter of his Problems of the Self, Bernard Williams introduces a distinction between different kinds of desires that he believes helps justify Elina's decision. According to Williams, conditional desires are those that are "conditional on being alive," whereas categorical desires are those by virtue of which one wants to be alive-or, as Williams puts it, desires that propel one "on into the future" (Williams, 1973, pp. 85-86). ${ }^{3}$ The desire for water or oxygen are paradigmatic examples of conditional desires. Conditional desires supposedly do not provide us reasons to go on living; they obtain because one is living. Anyone who wants oxygen normally does so only because oxygen is needed to stay alive, and they want to stay alive; as a rule, and outside chemistry labs, there seems to be no reason to want oxygen except because it is needed to stay alive. In contrast, categorical desires are those that motivate someone to get out of bed in the morning, that encourage her to plan for the future, and that make contemplating suicide seem absurd for her. Categorical desires vary rather widely from person to person. Some people want to be alive in order to watch their children grow up, others may want to go on living in order to finish writing the novel they have been working on, others still may want to live so they may continue fighting for a political cause in the hopes of changing society for the better. The list goes on.

According to Williams, then, Elina's problem was that she was alive for so long, that for every project she wanted to pursue, she had enough time to either finish it or lose interest to it. Without categorical desires, Elina's life became intolerably dull. Williams articulates this point rather succinctly:

Her trouble was, it seems, boredom: a boredom connected with the fact that everything that could happen and make sense to one particular human being of [37] had already happened to her. Or, rather, all the sorts of things that could make sense to one woman of a certain character (Williams, 1973, p. 90).

Once this happened, according to Williams, Elina had no reasons to live. As such, her decision to stop drinking from the elixir was perfectly rational. Notice that Williams does not think suicide was rational for Elina because her particular character was predisposed toward boredom. Rather, Williams believed this happened to her because, given enough time, any person would find themselves in Elina's position. ${ }^{4}$ Williams believed that, for creatures like us, "an eternal life would be unlivable" (Williams, 1973, p. 100). Williams' central argument may be represented in three simple subarguments.

\subsection{Williams' argument (Part 1):}

1. Every categorical desire is exhaustible.

2. If every categorical desire is exhaustible, then for any person $P$ who categorically desires $x$, there would come a time $t$ at which $P$ would no longer wish to pursue $x$.

Therefore,

3. For any person $P$ who categorically desires $x$, there would come a time $t$ at which $P$ would no longer wish to pursue $x$.

By "exhaustible," we mean that, with time, we will either satisfy our categorical desires or lose interest in them. Given enough time, your children will grow up and leave home, you will give up on writing that novel, you will 
witness the seeds of your political revolution yield fruit and change the world (or you will give up on wanting to pursue political revolution). Nothing, in particular, hangs on these examples. According to Williams, given enough time, you would either satisfy or lose interest in all categorical desires you currently have.

\section{2 | Williams' argument (Part 2):}

4. If for any person $P$ who categorically desires $x$, there would come a time $t$ at which $P$ would no longer wish to pursue $x$, then as long as she continues living, there will come a time $t$ in which $P$ either (a) becomes intolerably bored or (b) develops new, different categorical desires.

Therefore, given (3),

5. As long as she continues living, there will come a time $t$ in which $P$ either (a) becomes intolerably bored or $(b)$ develops new, different categorical desires.

So suppose you continue to live indefinitely, like Elina while she was drinking the elixir. If everything written above about categorical desires is correct, then at some point in the future you would cease to have categorical desires. You would run out of projects, of dreams, of goals-you would become utterly bored. ${ }^{5}$ Unless, of course, you develop completely new projects, dreams, and goals. But Williams argues, even completely new categorical desires would not make immortality desirable. This is one of the points on which Williams may be rightly challenged, and we will discuss such challenges shortly.

\subsection{Williams' argument (Part 3):}

6. If as long as she continues living, there will come a time $t$ at which $P$ either $(a)$ 's or $(b)^{\prime}$ 's then $P$ currently has no reason to continue living beyond $t$.

Therefore, given (5),

7. There is currently no reason for $P$ to continue living beyond $t$.

Consider option (a). On this horn of the dilemma, an agent maintains her "identity" yet runs out of categorical desires and becomes utterly bored. Williams contends that this sort of absolute boredom is sufficient for a meaningless life (Williams, 1973, p. 89). This likely stems from the intuition that a meaningful life requires some sense of fulfillment and passion, which a life of absolute boredom seemingly lacks. Moreover, Williams seems to believe that a meaningless life is one that provides no reason for one to continue living.

The second horn of the dilemma, option (b), is no better. Suppose "future-immortal-you" will manage to evade boredom by acquiring new, completely different categorical desires. Will that person, with entirely different beliefs, priorities, projects, and dreams be the same person as you? Williams seemed to at least allow that we could stave off boredom. But he thought this could only be achieved if our character changed so dramatically that our current selves would not be able to relate to our future selves in the right sort of ways. Our current selves would not see the value of us living such a radically different life in the future (if it is really us).

There are two ways to cash out this view. On one reading, Williams is understood as claiming that we would literally become different people after undergoing such radical change. ${ }^{6}$ On this reading, it is clearer why it would not be in our prudential interest to continue living. After all, it entails that you would not continue living. By taking on 
new categorical desires you would cease to be, and a new individual would pop into existence. On the second, more plausible, reading Williams is only understood as claiming that you would figuratively become a different person. ${ }^{7}$ On this reading, it is less clear why it would not be in your prudential interest to continue living, but the idea is not altogether implausible. To see why, consider a case introduced by Jeff McMahan:

The Cure: You're twenty years old and you've been diagnosed with an illness that will cause you to die within five years. Thanks to recent advancements in science and medicine, however, a cure for your illness has been developed. If you take the treatment, you'll live roughly sixty more years, years you can safely predict will be happy ones. But this is a recently developed treatment, with some noteworthy side effects. If you take it, you'll experience a radical personality change. The sports you currently like, you'll hate. The music you despise, you'll love. You'll befriend people you now find irksome, and lose touch with those who, today, are your closest companions. You'll make plans that would seem bizarre to you now, and work on projects you would've never have worked on otherwise. ${ }^{8}$

Would you take the treatment? We expect that most people would either hesitate or immediately oppose taking the cure. But if you refuse the cure, you will only live for 5 more years, as opposed to 60 more. One would expect that taking the cure and continuing to live would be in our prudential interest, and yet in this case, the stability of one's character over time intuitively outweighs considerations about life expectancy. If this intuition is correct, then Williams' suggestion may not be as implausible as it seems. It may be that we are, as he puts it, "lucky in having the chance to die" (Williams, 1973, p. 100).

\section{3 | REPLIES TO WILLIAMS}

\section{1 | Objections to premise (1)}

One reply offered by John Martin Fischer and Benjamin Mitchell-Yellin is that there are, in fact, some categorical desires that are not exhaustible. Suppose you have the desire to read all the novels in the world. You start your project at some time $t$, and at some later time $t^{*}$ you finish reading all novels that existed at $t$. But surely, new novels will have been published between $t$ and $t^{*}$-there will always be new novels to read. Some such projects, they argue, just cannot be completed, and if you are committed to pursuing them, they will motivate you to carry on living indefinitely (Fischer \& Mitchell-Yellin, 2014, p. 358). ${ }^{9}$ Others have proposed similarly open-ended projects as candidates for inexhaustible categorical desires. Neil Levy considers both the pursuit of truth and the quest for justice to be never-ending projects (Levy, 2005, p. 185). J. J. Wisnewski imagines someone who wishes to become the best musician in the world. After mastering all existing musical instruments, the musician begins to invent new ones, and so her job is never finished (Wisnewski, 2005, p. 34). More recently, inspired by Kierkegaard's work, Adam Buben has argued that self-development is yet another everlasting project. So long as one lives, "one can never be a finished and perfect person; there will always be another wrinkle to iron out, or at least the danger of one's earlier efforts being undone and in need of further attention" (Buben, 2016, p. 213).

In response to these suggestions, a proponent of Williams' argument may argue that the value of satisfying a desire diminishes every time you satisfy it. For instance, if your desire is to read books, for each time you read a book, doing so would become less and less interesting. Yet, if this is true, it also means that beyond a certain threshold, satisfying a given desire will not contribute to your well-being at all:

Diminishing Marginal Utility Threshold: For any desire $D$, there is some number $x$, such that if the amount of times a person has satisfied $D$ is greater than $x$, then any additional satisfaction of $D$ has no value. 
On this view, there will come a time when you have read so many novels that reading another one will bring no additional value to your life. You would no longer wish to pursue this project; reading will have become utterly dull. Shelly Kagan seems to gesture toward this sort of view. He argues that even if some categorical desires are not exhaustible in the sense that they can never be fully satisfied, that is not to say they are not exhaustible in the sense that they will ultimately lose their appeal. He puts the point rather vividly:

... you go through all the great art museums in the world (or the galaxy) and you say, "Yes, I've seen dozens of Picassos. I've seen Rembrandts and Van Goghs, and more. I've seen thousands, millions, billions of incredible works of art. I've gotten what there is to get out of them. Isn't there anything new?" .... There are, of course, things that you haven't seen before-but they are not new in a way that can still engage you afresh (Kagan, 2012, p. 243).

There are a few worries about this sort of objection. First, it seems objectionably ad hoc. What plausible principle could determine the rate at which the value of desire satisfaction decreases? A second worry about this sort of objection is that diminishing marginal utility functions are not obviously applicable to all sorts of desires. The pursuit of deep friendships and loving relations, for instance, seems like a good candidate for an exception. Fischer and Mitchell-Yellin argue that it would be absurd to say that, after experiencing a certain number of close special relations, finding any additional one will bring no value to one's life (Fischer \& Mitchell-Yellin, 2014, p. 360).

In a different essay, Fischer offers another response grounded on a distinction between self-exhausting pleasures and repeatable pleasures. Self-exhausting pleasures are those we expect someone will want to experience only once (or only a few times), perhaps wanting to reach the top of Mount Everest or solving some mathematical proof are examples. Repeatable pleasures are those we expect someone will want to experience multiple times, such as listening to your favorite song or watching fireworks on New Year's Eve (Fischer, 2009, p. 84-85). Fischer's insight is that while we obviously should apply a diminishing marginal utility function to categorical desires for self-exhausting pleasures (e.g., solving a mathematical proof you have already solved may seem less satisfying the second time around), applying that same function to categorical desires for repeatable pleasures only makes sense if those pleasures are poorly spaced-out in time. Surely, if you listen to your favorite song on a loop, you will eventually get sick of it and never want to hear it again. But if you rotate the tunes, making sure you space-out the times you listen to any individual song, repeated listens will not necessarily be any less fulfilling. ${ }^{10}$ So perhaps one's categorical desires need not be exhausted, at least if one works to acquire repeatable goods in their lives.

\subsection{Objections to premise (2)}

Christopher Belshaw has suggested that, unless our cognitive capacities are significantly enhanced if we were to become immortal, even if our categorical desires are exhaustible, it would not follow that, given enough time, people would either satisfy or lose interest in all their categorical desires. After all, we tend forget things as years go by and losing interest in one's categorical desires seemingly presupposes that one remembers all of the relevant experiences she had in the past. Belshaw puts the point like this:

My boredom at seeing Hamlet for the twentieth time depends not just on repetition, and my having seen it those nineteen times before, but also, to some considerable extent, on remembering, and in some detail what I have seen (Belshaw, 2015, p. 338).

Since there is no good reason to suppose that if we were immortal our cognitive capacities would (or need) be any different than they are now, immortality need not result in interminable boredom (Belshaw, 2015, p. 339). Imagine again an immortal who wants to read as many novels as she can. Think of how many plots she would forget 
throughout time. Imagine her reading and rereading them forever, never losing interest in her stories. Our faulty memories may just save us from eternal boredom.

Some find this reply deeply dissatisfying, even though they grant that such a life would not exhaust one's categorical desires. Such a life may seem meaningless, as one would not truly be doing anything importantly new, even if it seems that way to them (cf. Blumenfeld, 2009). Roy Perrett, for instance, believes that this sort of immortal life would be deeply "nauseating" (Perrett, 1986, p. 227). He would agree with Belshaw that our faulty memory could preserve our categorical desires indefinitely. But Perrett argues that an immortal life of continuous forgetfulness, though not boring, would be meaningless in virtue of the fact that the person in question systematically forgets her progress as she pursues some object of desire. According to Perrett, "either that goal can never occur, or it has already occurred an infinite number of times" (Perrett, 1986, p. 226). Neither option is one that Perrett believes contributes value to one's life. Imagine you have lived thousands of years. Even if you still find it satisfying, would not you wonder how many times you have read the same books, visited the same places, and learned the same things?

\subsection{Objections to premise (6)}

Another response comes from Thaddeus Metz, who argues that, despite what Williams may think, there are good reasons to believe that boredom is not sufficient for meaninglessness. For example, suppose Mother Teresa was utterly bored doing her work with the poor and sickly-every instant of it. If this were true, would Mother Teresa have lived a meaningless life? Hardly so. It stands to reason that "her life would have been significant, at least to some substantial degree, simply by virtue of having substantially helped so many needy people" (Metz, 2013, p. 135). You can also imagine someone who volunteers herself to be. Perhaps she is attending dull meetings or doing pointless administrative tasks-all in place of her colleagues. ${ }^{11}$ One might expect that her life gains some meaning from her self-sacrifice, as well as good reasons for living (Metz, 2013, p. 135). If this is right, then even if option (a) from Williams' dilemma obtains, it does not necessarily follow that the person in question has no reason to continue living.

Arguably, that does not follow from option (b) either. Taking McMahan's cure and finding yourself-millennia into your endless life-with a completely new set of categorical desires both have the same result: a radical character shift. But the analogy only goes so far. Only in the first case is this shift the result of an abrupt, immediate personality change. Although radically different, "30-year-old-you" and "1,000-year-old-you" are connected by a successive chain of events, where you progressively replaced your old categorical desires with new ones. As Sophie-Grace Chappell notes, even if one's "projects may be each of limited temporal duration, they may not all finish at oncethey overlap like the threads in a rope" (Chappell, 2009, p. 35). On Chappell's view, inasmuch as that will be her future and her projects, "30-year-old-you" has reason to care and continue living for the "1,000-year-old-you."12

Chappell's response, however, is not beyond dispute. Marya Schechtman argues that any "person can ... be robbed of her identity slowly as well as quickly" (Schechtman, 2001, p. 99). ${ }^{13}$ Indeed, depending on the sort of person who "1,000-year-old-you" will be, the prospect of gradually becoming her may seem even more disturbing to you than a quick transformation. ${ }^{14}$ Imagine gradually turning into a bad sort of political extremist or slowly becoming obsessed with golf (of all things!). Allowing yourself to undergo this process may not be in your self-interest after all.

Lastly, there is the concern that Williams' argument seems to prove too much. This is because, as David Benatar notes, it seemingly entails that our infant (or very young) selves have no reason to continue living into adulthood (2017, pp. 156-158). After all, the very young versions of ourselves lacked the categorical desires we currently have. One of us wanted to play soccer professionally when we were a child and simply had no comprehension of what being a philosopher entailed. Learning that our future self would become a philosopher would seem deeply weird, even alienating, to our younger self. Nevertheless, it seems absurd to hold that our younger self had no prudential reason to continue living into adulthood and beyond. But if our younger self had prudential reason to continue living into adulthood (even though this resulted in a series of radical character shifts and a completely new set of 
categorical desires), then why is not the same true for a person in their 30 s living another 300 years, and then another 300 years after that, and then so on ad infinitum?

Defenders of Williams might try to avoid this reductio ad absurdum by insisting that, in a mortal life, intense boredom or the prospect of an unattractive future only precludes reason to live immortal (not mortal) lives. This response, however, seems objectionably ad hoc and question begging. It also commits the Williams supporter to a mysterious asymmetry between the requirements a mortal person must meet to rationally choose to carry on living, and the requirements an immortal person must meet to do the same. ${ }^{15}$ In contrast, a perhaps more promising way to avoid the problem is by holding that although it is not rationally obligatory for someone to end her life once she runs out of old categorical desires, suicide remains rationally permissible nonetheless. So on this view, an infant could permissibly carry on living (or not). We believe this softened version of Williams' conclusion remains robustly counterintuitive, however. Surely young children with prospective good futures have prudential reason to continue living even if they cannot relate to their future selves in the particular ways Williams had in mind. Even if that were not the case, however, this move would still fail because it proves too little by Williams' own lights. This is because this revised view would still permit someone to rationally prefer immortality over mortality.

\section{4 | ARGUMENTS AGAINST IMMORTALITY FROM UNCERTAINTY AND RISK}

Suppose some of the previous replies to Williams' argument are convincing, and that, despite what Williams may think, there are many people who, by virtue of their particular categorical desires and psychological features, would manage to evade boredom and meaninglessness without undergoing radical and undesirable character changes as immortals. Despite this, one may argue that if you are uncertain you are one of these people, it would be irrational to wish for (or choose, if you had the option) immortality. In different papers, both David Beglin and A. G. Gorman provide novel arguments that most people are not in an appropriate epistemic position to develop an informed preference between mortality and immortality. ${ }^{16}$ If one is ignorant about which option would be better, the supposedly safe bet is sticking with a mortal life.

Beglin argues that even if there are inexhaustible categorical desires, it is unclear what it is for an immortal person to have meaningful projects and desires. Beglin worries that we would have so many categorical desires and long-standing projects throughout the course of our unending lives that each individual project would lose importance, as if "the significance of our substantive commitments would become diluted" (Beglin, 2016, p. 2020). His concern presumably stems from the intuition that our categorical desires are intimately related with what we prioritize-with what we value the most-in our finite lives. We appear to develop these evaluative attitudes toward certain projects and desires precisely because we only have a finite amount of time to complete (or satisfy) them. "It is unclear," he writes, "what life would be like without this evaluative perspective" (Beglin, 2016, p. 2025). ${ }^{17}$ This does not exclude the possibility that we could develop new ways to evaluate our activities if we were immortal. Beglin simply acknowledges that we do not know if we in fact would.

Gorman, in turn, emphasizes that any person must meet two conditions in order to evade boredom and meaninglessness without undergoing undesirable character changes if they were immortal. First, she must have at least one inexhaustible and infinitely interesting categorical desire. Second, she must not find it futile to work on a project with which she had already been engaged in the past but forgotten about. "For both conditions," they insist, "it seems the only way to know about whether or not one satisfies them is to have already lived far longer than an ordinary mortal life allows for" (Gorman, 2017, p. 1081).

Both Gorman and Beglin worry that if opting for an immortal life involves a nonzero chance of dooming oneself to eternal meaninglessness or unending boredom, there are strong reasons to avoid relinquishing one's mortality. While this is the intuitively correct (and seemingly risk adverse) position, we are not entirely convinced. Our objection to these lines of thought is that while choosing to be immortal would indeed be very risky (as we risk incurring 
interminable boredom), choosing to forgo immortality seems just as risky (as we risk missing out on infinite goodness). Therefore, insofar as it is rational to maximize expected value, we at least seem permitted to choose immortality.

\section{5 | ARGUMENTS AGAINST IMMORTALITY FROM FURTHER EMOTIONAL COSTS}

A different worry is that, even supposing we set the risk of eternal boredom aside, immortality would likely charge us with further, troubling emotional costs. Aaron Smuts, for instance, suggests that immortality would likely result in (a) a "motivationally devastating" condition (Smuts, 2011, p. 141), (b) "trivial victories of sheer diligence" (Smuts, 2011, p. 145), and (c) "endless frustration" (Smuts, 2011, p. 146).

His first worry is driven by the fact that we often feel strongly motivated to pursue and satisfy our categorical desires as soon as possible because we do not have all the time in the world-death gives us a deadline to finish our projects. If we were immortal, however, we "would risk nothing in delaying any given pursuit" (Smuts, 2011, p. 143). If we have an infinite amount of time ahead of us, and everything that can possibly occur will occur-and reoccur over and over again-why should we do anything now instead of later? Apathy and procrastination would, he thinks, ensue, and (a) would obtain. ${ }^{18}$ Now, perhaps you think that being the first to do or discover $x$ is sufficient reason to not postpone your pursuits. Anticipating this response, Smuts claims that, given enough time, people will forget that $x$ has been done or discovered. With infinite time, you will have the same chance to write Shakespeare's plays, or discover calculus, or bring about the Industrial Revolution, as if these things had never been done before. With this consideration, we return to an earlier worry: Why compete to be the first person to do or discover $x$ if at some point people will forget about $x$, at which time you will have the opportunity to have the exact same experience of being the first person to do or discover $x$ ? (Smuts, 2016, p. 143). One immediately salient response is that having the experience of being the first person to do $x$ is not the same accomplishment as actually being the first person to do $x$. One may reasonably want to truly be the first person to accomplish something rather than merely believing they are. ${ }^{19}$

Fischer and Mitchell-Yellin attempt to defuse this problem a different way. They draw a distinction between medical immortality and true immortality. ${ }^{20} \mathrm{~A}$ medically immortal person cannot die from natural causes-perhaps because all illnesses have been eradicated-but could, nonetheless, die from accidents, murders, bad stunts, and so on. A truly immortal person, though, is somehow completely invulnerable to death. True immortality is typically conceived of in theological terms, and it is hard to think of how we could be truly immortal if we were just physical beings. At least for the sake of argument, Fischer and Mitchell-Yellin were assuming that we are not under the protection of some special, unfailing supernatural being. This is an assumption Williams himself made. If this assumption is correct, then medical immortality is the best we can hope for, and even if we eventually become medically immortal, all of our choices would still be under some time constraint. Fischer's and Mitchell-Yellin's suggestion is that, by being medically immortal, an individual significantly reduces the chances of dying but does not eliminate them. "A medically immortal individual," they write, "could not safely assume that there will always be more opportunities to succeed in any undertaking" (Fischer \& Mitchell-Yellin, 2014, p. 366). So long as there is a nonzero chance that the medically immortal person dies sometime in the future, she will be motivated to pursue and complete her projects soon. ${ }^{21}$

Now, perhaps Williams was wrong and we are under the protection of a supernatural being, one who gave us true immortality. In that case, as mentioned in the previous paragraph, a number of projects (e.g., being the first to accomplish some goal) would still be under a time constraint and we could be motivated to pursue those goals. One other point is worth making as well. People tend to be temporally biased. All else equal, they prefer to have goods in the near future rather than distant future and bads in the distant future rather than the near future, even though this makes no difference to their total well-being. ${ }^{22}$ If we maintained our temporal bias once we knew we were truly 
immortal (and there seems to be no reason to assume that we would necessarily lose it), then we may still be motivated to pursue projects that are not time sensitive sooner rather than later.

Yet even if we were motivated to pursue our projects, in an immortal life, we might experience no real sense of accomplishment when we do achieve them. Just give enough time to a monkey with a typewriter, or to an octopus with a 3-D printer, and you will eventually get Shakespeare's plays and Michelangelo's David. ${ }^{23}$ It is in this way, Smuts worries, that an endless life seems conducive to $(b)$. "For immortals," he writes, "achievements are not something to be proud of. The products of the creative efforts of immortals are not necessarily the result of talent or skill, or 'moral and intellectual merits,' or anything else we, rightfully or not, feel pride in. No, immortals can achieve by mere diligence" (Smuts, 2011, p. 141).

Finally, Smuts believes that (c) follows from limited abilities. "Throughout the course of an eternal life, one would achieve all that one could ever hope to accomplish and then be frustrated by one's limitations indefinitely" (Smuts, 2011, p. 146). If you are not mathematically inclined or have weak lungs, you may never be able to invent calculus or climb Mount Everest-no matter how much time you have. More generally, if your abilities do not allow you to do or discover $x$, and you insist on trying to do so, you will find yourself eternally frustrated.

\section{6 | CONCLUSION}

Williams' anti-immortality argument has spawned an entire subliterature in the philosophy of death. In its simplest form, Williams' may be understood as posing a dilemma. An eternal existence, for creatures like us, would either result in the exhaustion of all of our categorical desires, thereby leading to an interminable boredom or result in us acquiring completely new categorical desires, thereby leading to the loss of our identity (either literally or figuratively). Neither option is good for us. Williams' argument is interesting and historically important, though there are good reasons to be skeptical that it is sound. Immortality optimists have argued that some categorical desires are not exhaustible, that in principle exhaustible categorical desires could be eternally resatisfied were our memories to remain imperfect, and that even a life of interminable boredom can be meaningful. Williams' work has also inspired related arguments. Some have argued that, given our epistemic uncertainty, choosing to live an immortal life would not be a risk worth taking. Others have argued that immortality would be undesirable because of certain emotional costs that would be incurred in such a life. This already rich literature is, relative to other philosophical literatures, in its infancy. It will not go on forever, but hopefully it will continue to grow until these questions are settled.

\section{ORCID}

Travis Timmerman (D) https://orcid.org/0000-0002-2693-5846

\section{ENDNOTES}

${ }^{1}$ For compelling evidence of this claim, see https://www.pewforum.org/2012/12/18/global-religious-landscape-exec/. Or, for the full report, see Hackett and Grim (2012).

${ }^{2}$ Although Elina is biologically 42 in Williams' recounting of the story, both Connie Rosati and Samuel Scheffler have noted that, at least in some versions of the play, Elina's biological age is 37 years old. See Rosati (2013, pp. 355-56), and Scheffler (2013, p. 91).

3 See Bradley and McDaniel (2013) and Rosati (2013) for insightful criticisms of this distinction.

${ }^{4}$ There is a caveat to this claim. People need not be immortal to suffer from extreme boredom and live monotonous lives. William recognizes that these people presumably would not get any more bored by living endless lives. He thinks most of us do not fall under this category, however (1973:91).

${ }^{5}$ See Bortolotti and Nagasawa (2009) and Gorman (2017) for sustained discussions about different accounts of boredom and the extent to which each relates to Williams' argument. See also Cholbi (2016) for an interesting argument that if categorical goods are exhaustible, then we should think that categorical bads are exhaustible too. Perhaps, then, an immortal life would cease to be bad, at least in this way, at some point. 
${ }^{6}$ William believes the first condition which must be satisfied for him to justifiably want immortality is "that it should clearly be me who lives forever" (Williams, 1973, p. 91). To satisfy this condition, someone who picks option (b) would be committed to the view that "survival by means of an indefinite series of lives" is possible. That is, to be consistent, you would have to believe that personal identity persists throughout time despite dramatic character changes. Williams is not sympathetic to this view. "Most, perhaps all, versions of this belief," he writes "... failed the first condition: they get nowhere near providing any consideration to mark the difference between birth and rebirth" (Williams, 1973, p. 92).

7 Williams submits that even if, despite your radical changes in character and categorical desires, you were still one person living one endless life, which is to say, even if personal identity were to persist through such a long time despite your "psychologically disjoint" personalities, he insists that a "problem remains of whether this series of psychologically disjoint lives could be an object of hope to one who did not want to die" (Williams, 1973, p. 92).

${ }^{8}$ McMahan (2002, p. 77). However, see Bradley (2008, § 2.1) and Bradley (2009, Chapter 4) for compelling arguments against commonsense judgments in The Cure. If Bradley is right, so long as personal identity is maintained, constancy of character is itself wholly irrelevant to prudential considerations.

9 For a similar argument, see John Martin Fischer's (1994) and his (2020, Chapter 7). Fischer has made a number of interesting moves against the Williams-style "immortality curmudgeons." See also his (2005), (2006), (2013), and his (2020, Chapters 6-10).

10 This point is also made in (Benatar, 2017, p. 156).

11 One might wonder whether this case illustrates the sort of boredom with which Williams is concerned. Can someone become bored (in Williams' sense) voluntarily? Maybe instead of volunteering herself to be bored, someone who already ran out of categorical desires follows instructions, for no particular reason, to perform boring tasks so her colleagues do not have to perform them. Whether she realizes it or not, by performing boring tasks in place of her colleagues her life becomes somewhat more meaningful.

12 See Smuts (2009, p. 137) for a similar claim.

13 It is perhaps worth thinking about Schechtman's argument using more neutral language, since one may reasonably worry that the phrase "robbed of her identity" is a bit loaded. Personal identity need not be lost with such variations in one's personality (or one's thick self), and the term "robbed" makes it sound as if these changes are caused by an outside agent and happen against one's will. Depending on the context, such changes (even radical ones) could be seen as positive or neutral, as well as negative. We thank an anonymous referee for raising these issues.

14 Derek Parfit gestures toward this worry when considering his famous Russian Nobleman thought experiment, where a young, philanthropic, nobleman is concerned that he will eventually become a greedy capitalist later in his life (1984, p. 327). Parfit's Russian nobleman believes it would be undesirable to become a greedy capitalist. A related worry is that, so long as our current selves do not know what it will be like to be these future selves, with radically different preferences and desires, our current selves cannot even assign an expected value to becoming these future selves to begin with. If this is right, then according to any expected utility model of rational decision-making, were we given the choice, there would be no rational way of deciding whether to become immortal (and risk gradually becoming such radically different versions of ourselves) or to remain mortal. For more on rational decision-making and radically different future selves, see Paul (2014). For an illuminating discussion that relates Parfit's Russian Nobleman case, L. A. Paul's work, and Schechtman's views on personal identity, to Williams' worries about immortality, see Altshuler (2016).

15 See Fischer (2009, p. 83) for a similar criticism.

16 In addition to Beglin (2017) and Gorman (2017), see Beglin () and Gorman ().

17 For similar claims, see Scheffler (2013, p. 99) and Altshuler (2016, pp. 198-200).

18 See Nussbaum (1994, p. 229), and May (2009, pp. 60-63) for similar claims. Though, Nussbaum is no longer a strict immortality curmudgeon. See her (2013).

19 We thank an anonymous referee for suggesting that we include this response to Smuts.

20 This sort of distinction was originally drawn in Cave (2012).

${ }^{21}$ See Metz (2013:137) for a similar suggestion.

${ }^{22}$ For a fascinating explanation of, and arguments against, the rationality of time bias see Greene and Sullivan (2015) and Sullivan (2018).

23 The value of plays or sculptures produced by random generalization may not be the same as the value produced intentionally by artists. A randomly produced "Hamlet" may have no artistic value, even though it might have a great deal of aesthetic value. 


\section{WORKS CITED}

Altshuler, R. (2016). Immortality, identity, and desirability. In M. Cholbi (Ed.), Immortality and the philosophy of death (pp. 191-203). Lanham, Maryland: Rowman \& Littlefield.

Beglin, D. (2017). Should I choose to never die? Williams, boredom, and the significance of mortality. Philosophical Studies, 174(8), 2009-2028.

Beglin, D. (forthcoming) Immortality, boredom, and standing for something. In M. Cholbi \& T. Timmerman (Eds.), Exploring the philosophy of death and dying: Classic and contemporary perspectives. New York: Routledge.

Belshaw, C. (2015). Immortality, memory and imagination. The Journal of Ethics, 19(3-4), 323-348.

Benatar, D. (2017). The human predicament: A candid guide to life's biggest questions. New York: Oxford University Press.

Blumenfeld, D. (2009). Living life over again. Philosophy and Phenomenological Research, 79(2), 357-386.

Bortolotti, L., \& Nagasawa, Y. (2009). Immortality without boredom. Ratio, 22(3), 261-277.

Bradley, B., \& McDaniel, K. (2013). Death and desires. In J. S. Taylor (Ed.), The metaphysics and ethics of death: New essays (pp. 118-133). New York: Oxford University Press.

Bradley, B. (2008). The worst time to die. Ethics, 118(2), 291-314.

Bradley, B. (2009). Well-being and death. New York: Oxford University Press.

Buben, A. (2016). Resources for overcoming the boredom of immortality in Fischer and Kierkegaard. In M. Cholbi (Ed.), Immortality and the philosophy of death. (pp. 205-219). Lanham: Rowman \& Littlefield.

Cave, S. (2012). Immorality: The question to live forever and how it drives civilization. New York: Random House.

Chappell, [S. G.]. (2009). Infinity goes up on trial: Must immortality be meaningless? European Journal of Philosophy, 17(1), 30-44.

Cholbi, M. (2016). Immortality, and the exhaustibility of value. In M.Cholbi (Ed.), Immortality and the philosophy of death. (pp. 221-236). Lanham: Rowman \& Littlefield.

Fischer, J. M. (1994). Why immortality is not so bad. International Journal of Philosophical Studies, 2(2), 257-270.

Fischer, J. M. (2005). Free will, death, and immortality: The role of the narrative. Philosophical Papers, 34(3), 379-403.

Fischer, J. M. (2006). Epicureanism about death and immortality. The Journal of Ethics, 10(4), 355-381.

Fischer, J. M. (2009). Our stories: Essays on life, death, and free will. New York: Oxford University Press.

Fischer, J. M. (2013). Immortality. In B. Bradley, F. Feldman, \& J. Johansson (Eds.), The Oxford handbook of philosophy of death (pp. 336-354). New York: Oxford University Press.

Fischer, J. M. (2020). Death, immortality, and meaning in life. New York: Oxford University Press.

Fischer, J. M., \& Mitchell-Yellin, B. (2014). Immortality and boredom. The Journal of Ethics, 18(4), 353-372.

Gorman, A. G. (2017). Williams and the desirability of body-bound immortality revisited. European Journal of Philosophy, 25 (4), 1062-1083.

Gorman, A. G. (forthcoming). Taking stock of the risks of life without death. In M. Cholbi \& T. Timmerman (Eds.) Exploring the philosophy of death and dying: Classic and contemporary perspectives. New York: Routledge.

Greene, P., \& Sullivan, M. (2015). Against time bias. Ethics, 125(4), 947-970.

Hackett, C., \& Grim, B. (2012). The global religious landscape: A report on the size and distribution of the world's major religious groups as of 2010. The Pew Forum on Religion \& Public Life, 1-68.

Kagan, S. (2012). Death. New York: Yale University Press.

Levy, N. (2005). Downshifting and meaning in life. Ratio, 18(2), 176-189.

May, T. (2009). Death: The art of living. New York: Routledge.

McMahan, J. (2002). The ethics of killing: Problems at the margins of life. New York: Oxford University Press.

Metz, T. (2013). Meaning in life: An analytic study. New York: Oxford University Press.

Nussbaum, M. (1994). The therapy of desire. Princeton: Princeton University Press.

Nussbaum, M. (2013). The damage of death: Incomplete arguments and false consolations. In J. S. Taylor (Ed.), The metaphysics and ethics of death: New essays (pp. 23-43). New York: Oxford University Press.

Parfit, D. (1984). Reasons and persons. New York: Oxford University Press.

Paul, L. A. (2014). Transformative experience. New York: Oxford University Press.

Perrett, R. W. (1986). Regarding immortality. Religious Studies, 22(2), 219-233.

Rosati, C. (2013). The Makropulos case revisited. In B. Bradley, F. Feldman, \& J. Johansson (Eds.), The Oxford handbook of philosophy of death (pp. 355-390). New York: Oxford University Press.

Schechtman, M. (2001). Empathic access: The missing ingredient in personal identity. Philosophical Explorations, 4(2), 95-111.

Scheffler, S. (2013). Death and the afterlife. New York: Oxford University Press.

Smuts, A. (2009). Wings of desire: Reflections on the tedium of immortality. Film \& Philosophy, 13(1), 137-151.

Smuts, A. (2011). Immortality and significance. Philosophy and Literature, 35(1), 134-149.

Sullivan, M. (2018). Time biases: A theory of rational planning and personal persistence. New York: Oxford University Press. 
Williams, B. (1973). Problems of the self. New York: Cambridge University Press.

Wisnewski, J. J. (2005). Is the immortal life worth living? International Journal for Philosophy of Religion, 58(1), 27-36.

\section{AUTHOR BIOGRAPHIES}

Felipe Pereira is an undergraduate student at Seton Hall University, majoring in philosophy and religious studies. Pereira's research ranges widely over normative ethics, well-being, and moral psychology. He is especially interested in attitudes we have due to our status as agents who exist over time (e.g., regret, gratitude, grief, hope, aspirations) and in various questions situated in the philosophy of love literature.

Travis Timmerman is an assistant professor of philosophy at Seton Hall University. He specializes in the philosophy of death and ethics. Much of his work focuses on axiological questions about death (e.g., can death be bad for the person who dies?) and the actualism/possibilism debate in ethics. He has also written on animal welfare, global poverty, and the debate over removing Confederate monuments.

How to cite this article: Pereira F, Timmerman T. The (un)desirability of immortality. Philosophy Compass. 2020;e12652. https://doi.org/10.1111/phc3.12652 